\title{
Some Biological Aspects of the Weed lesser Celandine (Ranunculus ficaria) ${ }^{1}$
}

\author{
Alguns Aspectos Biológicos da Planta Daninha Lesser Celandine (Ranunculus ficaria)
}

\author{
SOHRABI KERTABAD, S..$^{\star}$, RASHED MOHASSEL, M.H. ${ }^{3}$, NASIRI MAHALATI, M. ${ }^{4}$, and \\ GHEREKHLOO, J.5
}

\begin{abstract}
Lesser celandine (Ranunculaceae) is a perennial weed with tuberous root. Tubers are the most important means of reproduction and dispersion of this weed. In recent years, it has spread into wheat fields in Western Iran, mainly in the Lorestan province. A series of experiments were conducted to determine cardinal temperatures and to study the effects of pre-chilling, temperature fluctuations, tuber size, freezing and drying on germination of the tubers, as well as the effect of planting depth on sprouting of the tubers. The results obtained showed that the highest percentage of germination occurred when tubers were stored for more than 2 weeks at 4 or $8^{\circ} \mathrm{C}$. The optimum temperature for germination differed in large and small tubers ( 8 and $14^{\circ} \mathrm{C}$, respectively). Germination was the highest (almost 100\%) at temperature fluctuations of $5-10^{\circ} \mathrm{C}$. Germination of the finger-like and small tubers was the highest (95\%); however, very small, small, and broken tubers showed the lowest germination percentage. In the freezing experiment, decreasing the temperature and increasing the storage duration decreased the germination of tubers. Increasing the osmotic potential and temperature resulted in decreased tuber germination of Lesser celandine. Lesser celandine could sprout down to $20 \mathrm{~cm}$ depth but heat demand for tubers from superficial depth was smaller than for tubers planted at greater depth.
\end{abstract}

Keywords: freezing; germination; osmotic potential; tuberous root.

RESUMO - Celidônia, pertencente à família Ranunculaceae, é uma planta invasora perene com raiz tuberosa. Os tubérculos são o meio de reprodução e dispersão mais importante. Nos últimos anos, essa espécie começou a invadir lavouras de trigo no oeste do Irã, principalmente na provincia de Lorestan. Experimentos foram conduzidos para determinar as temperaturas limitrofes e estudar os efeitos de pré-resfriamento, flutuações de temperatura, tamanhos de tubérculos, congelamento e dessecação sobre a germinação de tubérculos, bem como da profundidade de plantio sobre a brotação de tubérculos. Os resultados mostraram que a maior porcentagem de germinação ocorreu quando os tubérculos foram armazenados por mais de duas semanas a 4 ou $8^{\circ} \mathrm{C}$. A temperatura ótima para germinação foi diferente em tubérculos grandes e pequenos $\left(8\right.$ e $14^{\circ} \mathrm{C}$, respectivamente). A germinação foi maior (quase $100 \%$ ) sob variações de temperatura entre 5 e $10{ }^{\circ} \mathrm{C}$. A germinação dos tubérculos digitiformes e pequenos foi maior (95\%), porém tubérculos muito pequenos, pequenos e danificados apresentaram o menor percentual de germinação. No experimento de congelamento, a redução da temperatura e o aumento no tempo de armazenamento diminuiram a germinação dos tubérculos. $O$ aumento do potencial osmótico e da temperatura resultou em diminuição da germinação de tubérculos de celidônia. Essa espécie pode brotar até a $20 \mathrm{~cm}$ de profundidade, mas a demanda de calor de tubérculos plantados superficialmente foi menor do que a dos tubérculos plantados em maior profundidade.

Palavras-chave: congelamento, germinação, potencial osmótico, raiz tuberosa.

Recebido para publicação em 4.6.2012 e aprovado em 25.12.2012

2 Ph.D. Student in Weed Science, Department of Agronomy, Ferdowsi University of Mashhad, Iran, <simsoh@gmail.com>; ${ }^{3}$ Professor, Department of Agronomy, Ferdowsi University of Mashhad, Iran, <mhrmohasel@yahoo.com>; ${ }^{4}$ Professor, Department of Agronomy, Ferdowsi University of Mashhad, Iran, <nassiri20@yahoo.com>; 5 Assistant Professor, Department of Agronomy, Gorgan University of Agricultural Sciences and Natural Resources, Gorgan, Iran, <gherekhloo@yahoo.com>; ${ }^{6} \mathrm{PhD} \mathrm{Student} \mathrm{in} \mathrm{Weed}$ Science, Department of Agronomy, Ferdowsi University of Mashhad, Iran, Postal Code: 9171948978-1163, <simsoh@gmail.com>; * Corresponding author.

Planta Daninha, Viçosa-MG, v. 31, n. 3, p. 577-585, 2013 


\section{INTRODUCTION}

Lesser celandine (Ranunulus ficaria), also known as fig buttercup, is an herbaceous, perennial species of the family Ranunculaceae. It is a spring ephemeral and a vigorous growing groundcover weed that forms large, dense patches on the garden and forest floor, displacing and preventing native plants from co-occurring. It has shiny dark green and kidney-to-heart-shaped, petiolate leaves (Copson \& Roberts, 1991). This weed is an unusual dicotyledon because it has seedlings with a single cotyledon (Taylor \& Markhame, 1978). It reproduces primarily by producing and dispersing subterranean bulblets or tubers (Swearingen, 2004; Axtell et al., 2010). Initial establishment is probably accomplished by seeds, although roots can be carried in boots, horse hooves, mower decks and equipment tires. Once established, expansion is probably vegetative with large clonal stands forming monocultures that completely crowd out native forest floor plants (Mack, 2008). The first basal tubers develop adventitious roots on the auxiliary buds of the basal leaves (Taylor \& Markhame, 1978). Later subterranean tubers are formed by the appearance of new root initials and buds on the existing tubers. The tubers enter a 6-month resting phase at the end of May. After the shoots of the plant die down, a distinct white bud develops and gradually enlarges on the newly formed group of root tubers. Other smaller buds may also develop (Taylor \& Markham, 1978).

The resting buds on the root tubers turn green and begin to elongate around December and numbers of adventitious roots begin to develop. The foliage leaves of the basal rosette begin to unfold in January (Grime et al., 1988). The bulbils or tubercles that develop on the leaf axils are similar to the basal tubers (Taylor \& Markhame 1978).

Fragmentation of the groups of basal tubers into individual units, each with a single bud, is an efficient means of vegetative propagation (Taylor \& Markham, 1978). The onset of senescence is at a time when day length is long and temperature and light levels are high (Swearingen, 2004). There are two subspecies of this weed, Ranunculus ficaria ssp. Bulbifera and ssp. Ficaria. In subspecies Bulbifera, the leaf bulbils tear off as the leaves die down. It can develop up to 24 bulbils per plant (Sell, 1994). However, according to Grime et al., (1988), this subspecies would rather be a woodland plant and R. ficaria ssp. ficaria is mainly found in open and disturbed habitats and gardens.

Weed biology plays an important role in fitness, competitiveness and adaptations of weeds in agroecosystems. This weed is a native plant of Eurasia and has become increasingly invasive in western Iran, especially in wheat fields (Figure 1). Increased knowledge of tuber germination biology of this species would facilitate the development of optimal control programs. This study aimed to determine the effects of some factors on tuber germination of $R$. ficaria to improve the management of this weed as part of weed management programs. Our particular goal was to examine the effect of temperature, freezing, drying, pre-chilling and tuber size on rate and percentage of tuber root germination. We also investigated seedling emergence of lesser celandine at different sowing depths.

\section{MATERIALS AND METHODS}

Tubers were collected from a wheat field located in the South Western Khorramabad, Iran, during May 2008.

The tubers of lesser celandine were sterilized for 4 minutes in $1 \%$ sodium hypochlorite solution. Parts of the tubers were placed in germinators at 10 and $15{ }^{\circ} \mathrm{C}$ for two weeks. Lack of germination at both temperatures indicated that all buds were dormant. Therefore, pre-chilling experiments were conducted in order to break the dormancy of the tubers.

A pre-chilling experiment was carried out in a completely randomized design in a factorial arrangement of treatments and four replications. The factors included storage duration in refrigerator $(7,14,21$ and 28 days) and storage temperature $\left(2,4\right.$ and $\left.8{ }^{\circ} \mathrm{C}\right)$. Five tubers were placed on top of moist filter paper on each Petri dish. Each Petri dish was considered as one experimental unit, and taken to a refrigerator. When the pre-chilling periods were completed, the tubers were 


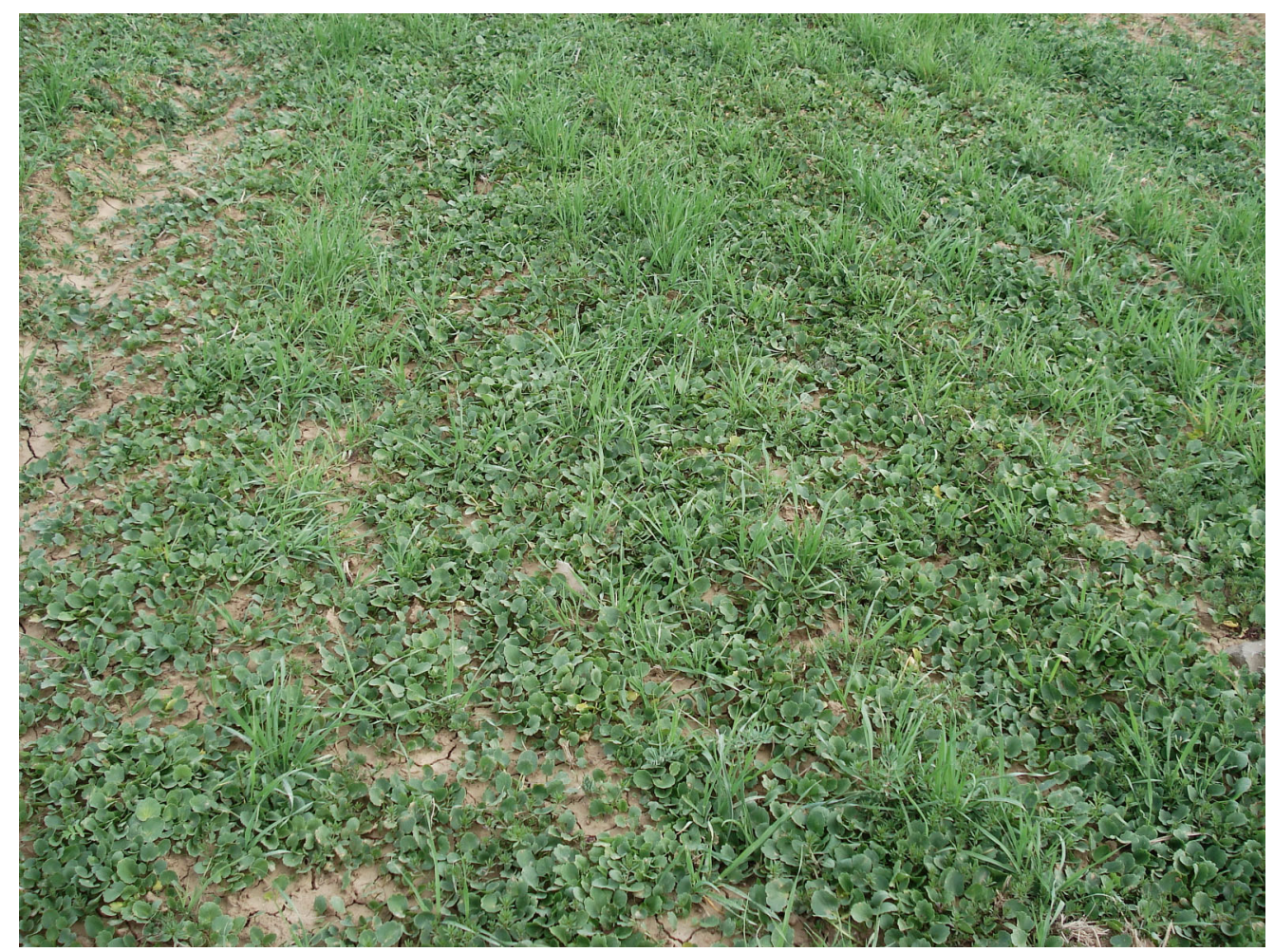

Figure 1 - Lesser celandine in a wheat field in Lorestan province, Iran.

placed in a germinator in the dark for 20 days at $14{ }^{\circ} \mathrm{C}$ with $60 \%$ moisture.

Another experiment was conducted in a completely randomized design with four replications to evaluate the effect of tuber size on germination. The tubers were categorized into six size groups: very small $(<0.02 \mathrm{~g})$, small (0.03-0.04 g), medium (0.06-0.12 g), finger-like (0.15-0.64 g), tall (0.1-0.27 g) and broken $(0.07-0.18 \mathrm{~g})$. Each group was considered as one treatment. Five tubers of each group were placed on moist filter paper on each Petri dish (with $5 \mathrm{ml}$ distilled water). The Petri dishes were placed in a germinator for 20 days at $14{ }^{\circ} \mathrm{C}$. Every other day, the Petri dishes were checked and the tubers with visible sprouts were considered as germinated tubers. On this basis, the germination percentage and germination rate (number of germinated tubers per day) were calculated. Germination rate was estimated using Equation 1 (Kurtar, 2010).

$$
R s=\sum_{i=1}^{n} \frac{S i}{D i}
$$

where $R s$ : germination rate, $S$ : number of germinated tubers per day, $D:$ number of days and $i$ number of days to final observation.

In order to determine cardinal temperature, tubers were grouped into two sizes according to their fresh weight (large $>0.2$ and small<0.05 g). Each group was subjected to temperatures $1,5,10,15,20$ and $25^{\circ} \mathrm{C}$, and their germination rate was measured for a period of 20 days. Cardinal temperatures were estimated by regression analysis for germination rate (GR) and temperature (T) using the Intersecting lines Model (ISL) (Equation 2).

$$
\begin{aligned}
& G R=b *\left(T-T_{b}\right) \text { if } T \leq T_{o} \\
& G R=C *\left(T_{c}-T\right) \text { if } T \geq T_{o}
\end{aligned}
$$

where $T_{b}, T_{o}$ and $T_{c}$ are the base, optimum and ceiling temperature, respectively and $a$, $b$ are the regression coefficients (Craigon et al., 1999). We defined this model as a nonlinear regression model in Sigma Plot version 8 . 
To study the effect of fluctuating temperature on tuberous root germination, the tubers were treated with different temperature periods including $5 / 10,7 / 12,10 /$ 15 and $15 / 25^{\circ} \mathrm{C}(13 \mathrm{~h}$ night $/ 11 \mathrm{~h}$ day period $)$ with 4 replications. The Petri dishes were placed in a germinator for 20 days at $14^{\circ} \mathrm{C}$. Every other day, the Petri dishes were checked for germination.

To investigate the effect of freezing and desiccation on germination of lesser celandine tubers, two separate experiments were conducted in a completely randomized design in a factorial arrangement of treatments and four replications. The factors in freezing experiment included time of exposure to freezing (12, 24, 48 and 96 hours) and freezing temperature $\left(0,-5,-10\right.$ and $\left.-15{ }^{\circ} \mathrm{C}\right)$. To study the effect of desiccation on tuber root germination, the following factors were included: temperature at five levels $(5,10,15,20$ and $\left.25^{\circ} \mathrm{C}\right)$, osmotic potential at four levels $(0,-5$, -10 and -15 bar) and tuber size at two levels $[\mathrm{big}(>0.2 \mathrm{~g})$ and $\operatorname{small}(<0.05 \mathrm{~g})]$. Germination rate and percentage of germinated tubers were calculated.

To evaluate the effect of planting depths on sprouting, the tuberous roots were planted at 0.25 (superficial), 1.5, 2.5, 5, 7, 10, 15 and $20 \mathrm{~cm}$ depths in pots with $25 \mathrm{~cm}$ diameter and $50 \mathrm{~cm} \mathrm{depth}$. For each depth, date of sprouting and number of seedlings were measured as soon as they emerged.

Statistical analysis was performed using Minitab ver. 13. Mean separation was performed by the LSD test at $5 \%$ probability level.

\section{RESULTS AND DISCUSSION}

\section{Effects of pre-chilling}

The results showed that duration and temperature of pre-chilling had a significant effect on tuber germination. Percentage and rate of germination were the highest at $4{ }^{\circ} \mathrm{C}$ on the $28^{\text {th }}$ day (Figures 2 and 3 ). No significant differences were observed in the germination of the tubers between 2 and 4 weeks of prechilling. A pre-chilling treatment at $2{ }^{\circ} \mathrm{C}$ for 7 days reduced tuber germination by $40 \%$. According to the results, the dormancy of newly produced lesser celandine tubers could be broken by low temperature. Tuber dormancy was reported to be broken by chilling (Grime et al., 1988). Maintaining tubers of $R$. ficaria ssp. bulbifera at $15-20{ }^{\circ} \mathrm{C}$ prolongs the resting phase indefinitely (Taylor \& Markham, 1978). Lesser celandine is often difficult to control, because its storage organ often remains dormant for many months; therefore, it survives fallows. The length of the resting period of the tubers of $R$. ficaria depends on the temperature, but is not affected either by day length or irradiance level (Markham, 1970).

Tuberous roots of Ranunculus asiaticus require exposure to low temperature averaging $4-5{ }^{\circ} \mathrm{C}$ for $4-5$ weeks or $2{ }^{\circ} \mathrm{C}$ for 2 weeks applied prior to planting for breaking dormancy and starting growth (Ohkawa, 1986). Low temperature requirement is also reported for tubers of Anemone coronaria, which could germinate after exposure to $2-10{ }^{\circ} \mathrm{C}$ for

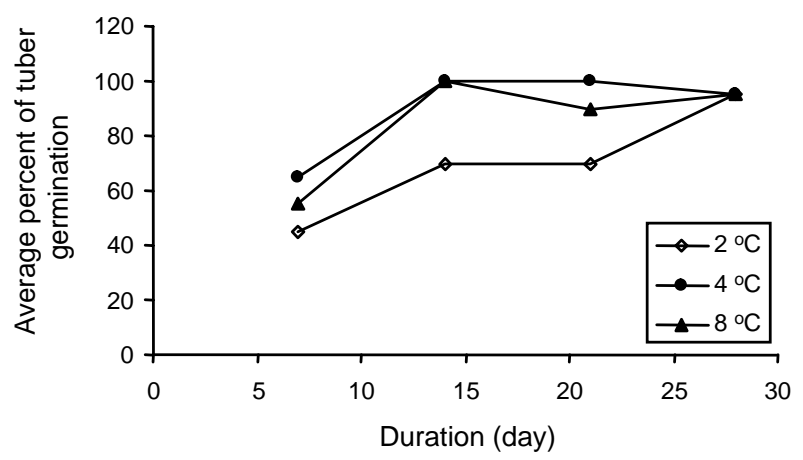

Figure 2 - Effect of pre-chilling duration and temperature on germination of Lesser celandine $(\mathrm{LSD}=0.98)$.

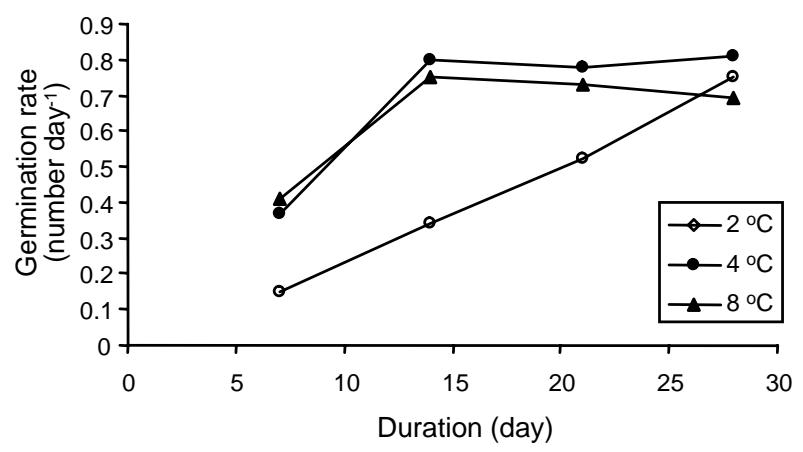

Figure 3 - Effect of pre-chilling duration on germination rate of Lesser celandine tubers 
4-6 weeks (Le Nard et al., 1993). Geophytic species respond to many environmental signals such as temperature, moisture, and photoperiod that determine when to enter or exit dormancy. For example, tuberous root formation of Dahlia hybrids $(D$. coccinea $\mathrm{x}$ D. pinnata) is induced by photoperiods of 11-12h or less. Their dormant tuberous roots do not immediately resume growth unless they have been exposed to 0 to $10{ }^{\circ} \mathrm{C}$ for 6 weeks (Konishi \& Inaba, 1967; Moser \& Hess, 1968). Geophytes are found in a range of climates from tropical to arctic and, therefore, they differ greatly in response to temperature. Species such as tulip require exposure to temperatures averaging $5{ }^{\circ} \mathrm{C}$ for at least 10 to 12 weeks to break dormancy (Le Nard \& Dehertogh, 1993). In Ranunculus asiaticus, cold treatment of bulbs at $5{ }^{\circ} \mathrm{C}$ for 4 weeks led to flower primordia (sepals) initiation in all plants 25 days after planting. However, the sprouting of bulbs stored at $0{ }^{\circ} \mathrm{C}$ was delayed for 60 days compared to bulbs stored at $20{ }^{\circ} \mathrm{C}$ (Ohkawa, 1986).

\section{Size effects of tubers}

The results indicated that tuber size had significant effect on germination. The fingerlike group and small tubers had the highest percentage of germination, while the medium, broken, very small and tall tubers showed $70 \%$, $50 \%, 45 \%$ and $35 \%$ germination, respectively (Figure 4). However, no significant difference was observed among broken, very small and tall tubers. During the study, only tall tubers were highly affected by root rot (45\%). Germination rate was the highest in the finger-like group

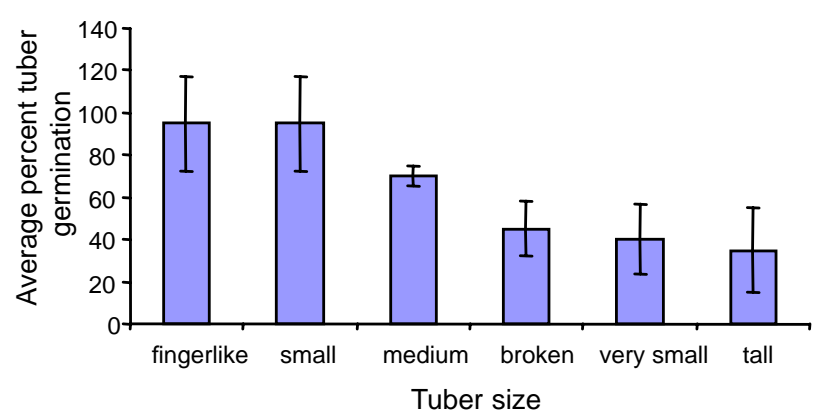

Figure 4 - Effect of tuber form on the germination of Lesser celandine $(\mathrm{LSd}=0.89)$ and small tubers (Figure 5). By the end of the experiment, the fingerlike group had produced about $60 \%$ fibrous roots while the other groups produced few roots only (about 10\%).

The finger-like group tubers with sufficient reserves and small tubers with lower respiration possibly have higher germination percentage than other forms of tubers. The percentage of smaller tuber size was reduced as a result of decreased availability of storage tissues to support tuber germination. Lower germination rate in the tall tubers may be due to high respiration rate and susceptibility of these types of tubers to disease.

Sufficient reserves are especially important in perennial plants in regions with cold winters. Spring growth of these plants strongly depends on food reserves accumulated during the previous season (Shaver \& Billings, 1976; Klimes et al., 1993; Kubin \& Melzer, 1996).

A very efficient means of vegetative propagation is the fragmentation of the basal group, in such a way that each unit has at least one bud, thus possessing the potential for new growth (Markham, 1970).

\section{Cardinal temperatures}

According to the results, optimum temperature was different in large and small tubers. The optimum temperature was about $8{ }^{\circ} \mathrm{C}$ and $14{ }^{\circ} \mathrm{C}$ for large and small tubers, respectively (Table 1). Base and ceiling temperatures in both sizes were similar and about $0{ }^{\circ} \mathrm{C}$ and $25^{\circ} \mathrm{C}$, respectively. Because they had more food reserves, large tubers could grow at low temperatures when compared

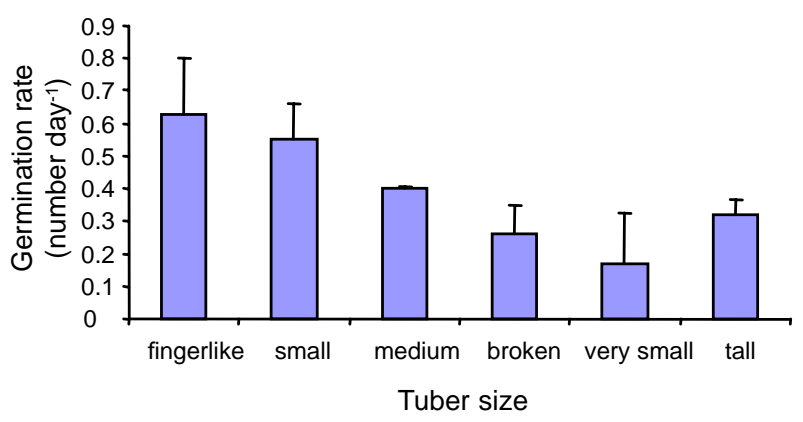

Figure 5 - Germination rate of six tuber forms of Lesser celandine.

Planta Daninha, Viçosa-MG, v. 31, n. 3, p. 577-585, 2013 
Table 1 - Cardinal temperature of Lesser celandine based on the ISL model $\left(\mathrm{T}_{\mathrm{b}}, \mathrm{T}_{0}\right.$ and $\mathrm{T}_{\mathrm{c}}=$ base, optimum and ceiling temperature respectively)

\begin{tabular}{|c|c|c|c|}
\hline \multicolumn{2}{|c|}{$\begin{array}{c}\text { Small tubers }(<0.05 \mathrm{~g}) \\
\mathrm{R}=0.99\end{array}$} & \multicolumn{2}{|c|}{$\begin{array}{c}\text { Large tubers }(>0.2 \mathrm{~g}) \\
\mathrm{R}=0.96\end{array}$} \\
\hline $\begin{array}{c}\text { Cardinal } \\
\text { temperature }\left({ }^{\circ} \mathrm{C}\right)\end{array}$ & $\mathrm{SE}$ & $\begin{array}{c}\text { Cardinal } \\
\text { temperature }\left({ }^{\circ} \mathrm{C}\right)\end{array}$ & $\mathrm{SE}$ \\
\hline $\mathrm{T}_{\mathrm{b}}=-0.6$ & 0.59 & $\mathrm{~T}_{\mathrm{b}}=0.25$ & 2.02 \\
\hline $\mathrm{T}_{0}=14$ & - & $\mathrm{T}_{0}=8$ & - \\
\hline $\mathrm{T}_{\mathrm{c}}=25$ & 0.49 & $\mathrm{~T}_{\mathrm{c}}=24$ & 2.78 \\
\hline
\end{tabular}

ISL: Intersecting lines Model.

to small tubers. In general, large tubers had higher germination than small tubers (Figures 6 and 7).

It has been reported that the size of $R$. ficaria tubers is an important factor in determining the length of the dormant period. Within the range of tuber sizes in the field population, larger tubers developed faster than smaller tubers when exposed to low temperatures $\left(5{ }^{\circ} \mathrm{C}\right)$ (Taylor \& Markham,

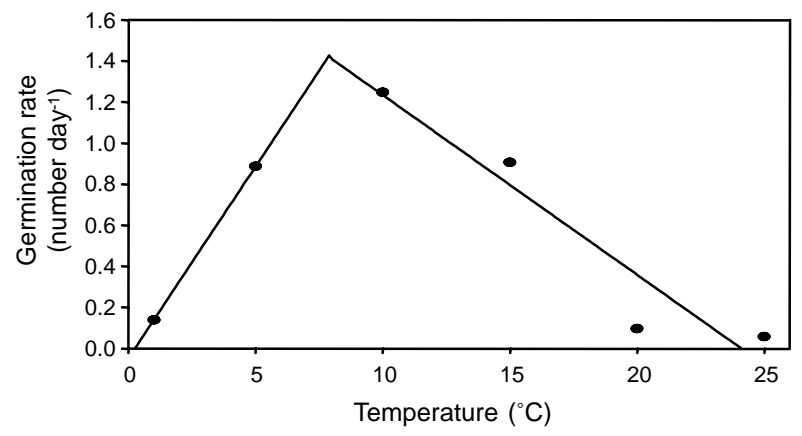

Figure 6 - Cardinal temperature for large tubers $(>0.2 \mathrm{~g})$ of Lesser celandine

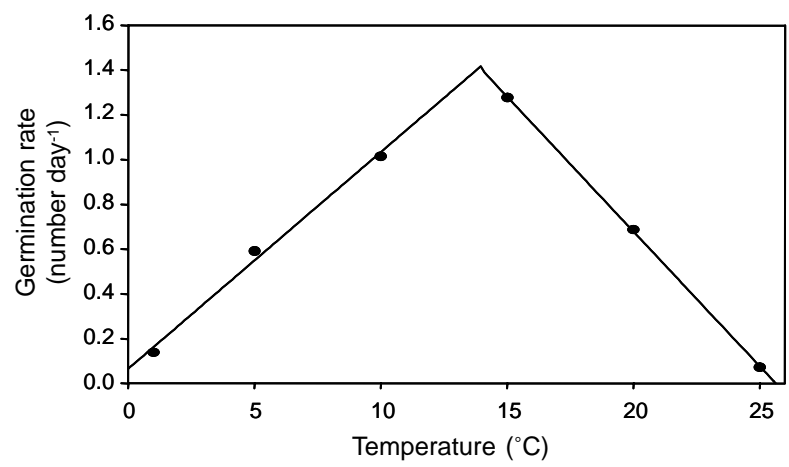

Figure 7 - Cardinal temperature for small tubers $(<0.05 \mathrm{~g})$ of Lesser celandine.
1987). Likewise, for other perennial geophytes, size and age of the bulbs are determinant factors for their ability of reproductive development (Maria et al., 1995).

Plants must attain proper photosynthetic storage capacity before being subjected to reproductive conditions. In addition, early exposure to reproductive conditions before storage organs reach sufficient size (end of juvenility) may decrease uniformity of flowering (Cameron et al., 1996). In all populations of $R$. ficaria, plant size is an important factor in flowering: the larger the initial tuber weight, the greater the tendency of flowering (Taylor \& Markham, 1978). In both woodland and open habitats, early growth takes place in short days when temperatures and light levels are low (Swearingen, 2004).

\section{Temperature fluctuations}

The results indicated that the percentage and rate of germination were the highest at 5 $10{ }^{\circ} \mathrm{C}$ and $7-12{ }^{\circ} \mathrm{C}$. Percent of germination was strongly reduced at $15-25^{\circ} \mathrm{C}$. Germination rate of Lesser celandine also progressively declined at $15-25{ }^{\circ} \mathrm{C}$ (Figure 8 and 9). In purple nutsedge (Cyperus rotundus), it was found that total tuber sprouting and germination rate increased significantly after a shift of daily temperature fluctuation from 0 to $12{ }^{\circ} \mathrm{C}$ (Travlos et al., 2009)

\section{Effect of freezing}

Freezing temperature, duration of freezing and their interactions had significant effect on germination of tubers. Decreasing the temperatures and increasing storage duration decreased the germination of tubers. The germination of tubers did not occur when tubers were stored beyond 48 hours at $-10{ }^{\circ} \mathrm{C}$ and $-15^{\circ} \mathrm{C}$. The effect of freezing on germination was increased when tubers were exposed to $-5{ }^{\circ} \mathrm{C}$ for more than 24 hour. There was no difference in germination of tubers at $0{ }^{\circ} \mathrm{C}$ in all storage durations (Figures 8 and 9).

The below-ground organs of $R$. ficaria showed a range of cold resistance between 1.5 to $-8.5{ }^{\circ} \mathrm{C}$, compared with -1.5 to $-5.5^{\circ} \mathrm{C}$ in Anemone nemorosa and -1.5 to $-6.5^{\circ} \mathrm{C}$ in Mercurialis perennis (Taylor \& Markham, 1978). 


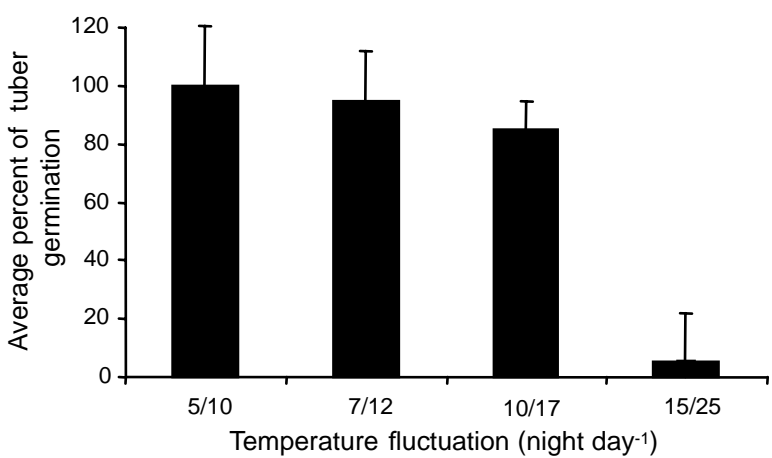

Figure 8 - Effect of temperature fluctuation on germination percentage of Lesser celandine.

\section{Desiccation effect}

Results showed that drought stress had significant effect on germination of tubers. Increasing the osmotic potential and temperature decreased the germination of R. ficaria tubers (Figures 10 to 13). Germination did not occur in all temperatures with osmotic potential of - 15 bars. No significant difference was observed among large and small tubers although $R$. ficaria is always found in soils which are moist in spring, while growing regions are dry in summer (Taylor \& Markham, 1978). Lesser celandine is more resistant to drought after plant senescence. Growth is poor in dry areas and therefore plants senescence starts earlier (Bond et al., 2007). Lesser celandine occurs on lands that are seasonally wet or flooded, but this species is absent from permanently waterlogged sites (Swearingen, 2004).

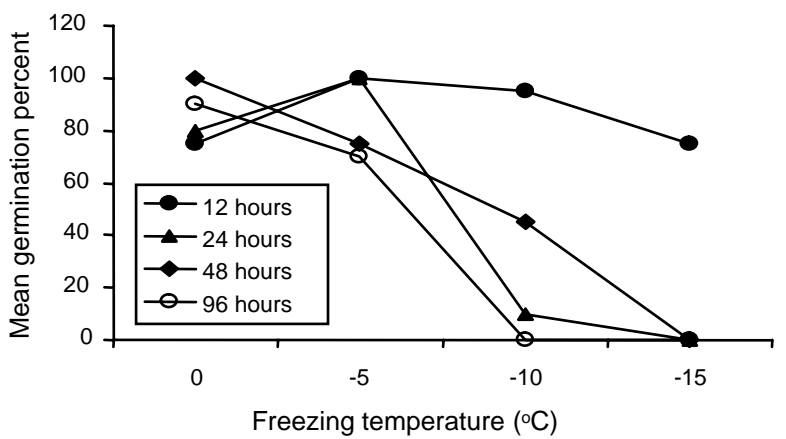

Figure 10 - Effect of freezing on germination of Lesser celandine tubers.

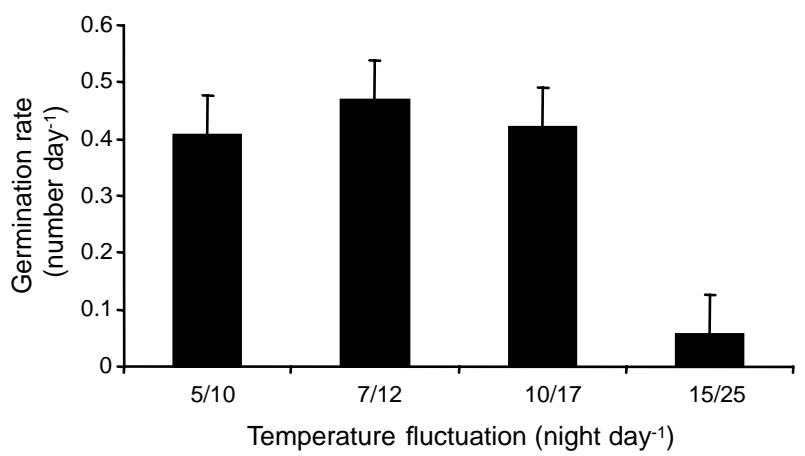

Figure 9 - Effect of temperature fluctuation on germination rate of lesser celandine.

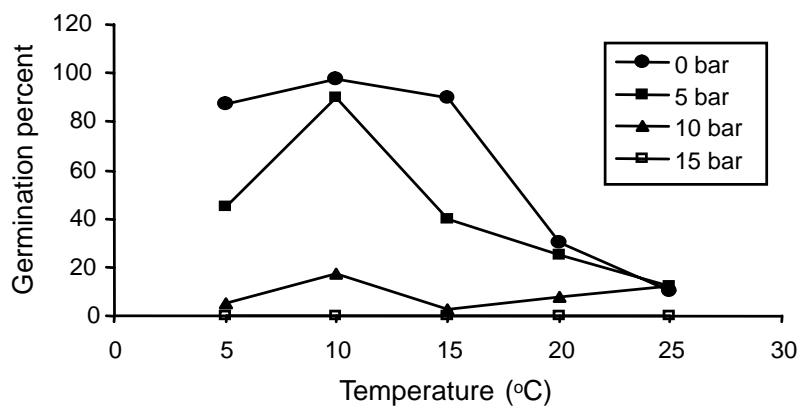

Figure 11 - Effect of drying on germination of Lesser celandine.

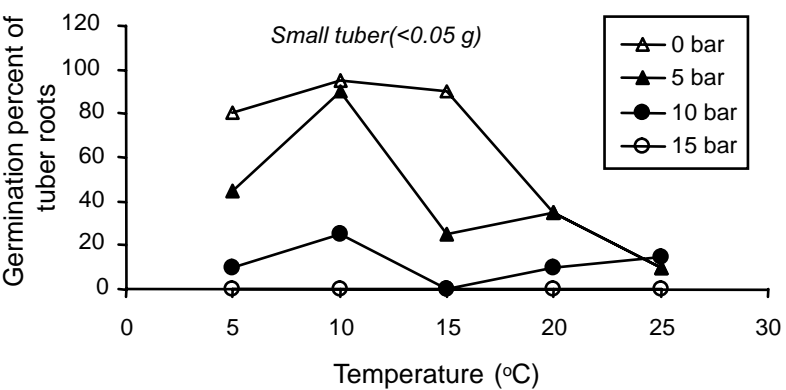

Figure 12 - Effect of drying on germination of small tubers of Lesser celandine.

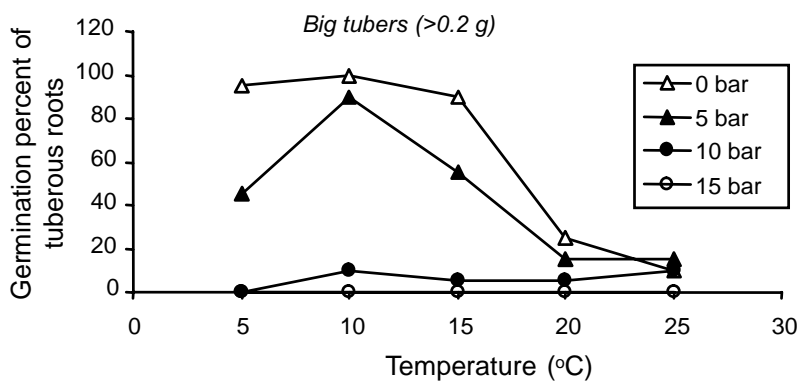

Figure 13 - Effect of drying on germination of big tubers of Lesser celandine.

Planta Daninha, Viçosa-MG, v. 31, n. 3, p. 577-585, 2013 


\section{Effect of planting depth}

Lesser celandine tubers could sprout in all depths, but there were fewer heat units for superficial depth than the amount required by tubers at 15 and $20 \mathrm{~cm}$ depths (Figure 14). Emergence occurred earlier on the upper layer of the soil than in higher depth. Increasing $1 \mathrm{~cm}$ in the planting depth delayed emergence of seedlings for about 1 day. Maximum seedling emergence of Melilotus officinalis occurred when the seeds were placed at $2 \mathrm{~cm}$ depth and decreased when depth of planting was increased; no seed emerged from $10 \mathrm{~cm}$ depths (Ghaderi-Far et al., 2010). Decrease in seedling emergence due to increasing planting depth has been reported in several weed species (Lu et al., 2006; Norsworthy \& Oliveira, 2006; Vidal et al., 2007).

If lesser celandine is very abundant, it may be a better idea not only to plough the soil so as to leave the bottom of the ploughed part upwards but also grow root crops for 1-2 years before sowing grass species again (Bond et al., 2007).

$R$. ficaria is an invasive perennial weed in winter crops fields in the west of Iran. Dense growth of this weed decreases crops yield. As lesser celandine grows in low temperatures, when winter crops (such as wheat and barley) are in rosette stage, this weed continues to grow and produces new tubers. Herbicides are usually applied in fields at the time that this invasive weed has produced new tubers and almost completed its life cycle. Thus, the current chemical control method does not affect the survival and density of the weed.

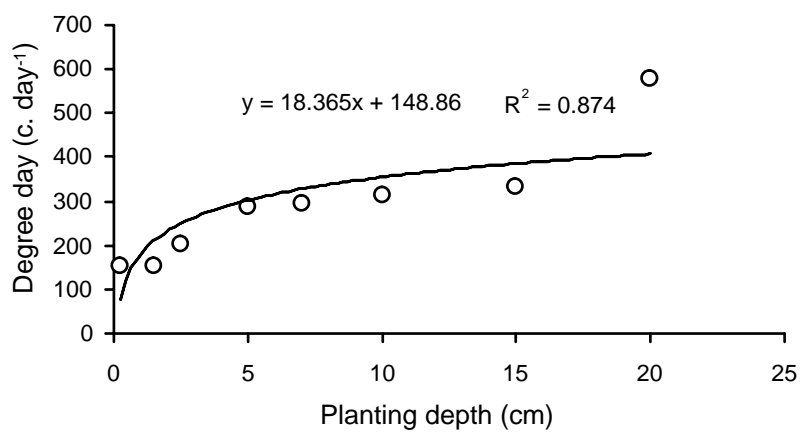

Figure 14 - Effect of planting depth on sprout time of tubers Lesser celandine.
According to the results, plowing in warm and dry summer and water freezing in winter in fallowed fields possibly decreases density of this invasive weed in infested fields. As the very small tubers could germinate and produce new plants, shallow tillage in the infested soils results in fragmentation of the tubers with increased occurrence of lesser celandine. Plowing with depth over $15 \mathrm{~cm}$ delays the emergence and growth of $R$. ficaria, overtaking the growth of the crop; this will help the crop to perform better and overcome weed in the competition.

\section{ACKNOWLEDGMENTS}

We appreciate the cooperation of the Agricultural Research Center of Lorestan and would like to thank all those who helped us in collecting the tubers.

\section{LITERATURE CITED}

AXTELL, A. E. et al. Lesser celandine (Ranunculus ficaria): A Threat to woodland Habitats in the Northern United states and southern Canada. Invasive Plant Sci. Manag., v. 3, n. 2 , p. 190-196, 2010.

BOND, W. et al. The Biology and nonchemical control of lesser cleandine. HDRA. 2007. Available from URL: <http:// www.gardenorganic.org.uk/organicweeds $>$. Accessed: Jan. 12 2012.

CAMERON, A. et al. Juvenility: Your perennial crops age affects flowering. Grower Talks, v. 60, n. 8, p. 30-32, 1996.

COPSON, P. J.; ROBERTS, H. A. Garden weeds -a survey in Warwickshire. Profes. Hortic., v. 5, n. 1, p. 71-73, 1991

GRIME, J. P. et al. Comparative plant ecology: a functional approach to common British. London: Unwin Hyman, 1988. $742 \mathrm{p}$.

GHADERI-FAR, F. et al. Influnce of environmental factors on seed germinaton and seedling emergence of yellow sweet clover (Melilotus officinalis). Planta Daninha, v. 28, n. 3, p. 463-469, 2010.

KLIMES, L. et al. Regeneration capacity and carbohydrate reserves in a clonal plant Rumex alpinus: effect of burial. Vegetatio, v. 109, n. 2, p. 153-160, 1993.

CRAIGON, J. et al. The germination response of Bambara groundnut (Vigna subterranea L. Verdc) to temperature. Seed Sci. Technol., v. 27, n. 1, p. 303-313, 1999. 
KONISHI, K.; INABA, K. Studies on flowering control of Dahlia. VII. On dormancy of crown-tuber. J. Japanese Soc. Hortic. Sci., v. 36, n. 1, p. 31-140, 1967.

KUBIN, P.; MELZER, A. Does ammonium affect accumulation of starch in rhizomes of Phragmites australis (Cav.) Trin. ex Steud.?. Folia Geobot. Phytotax., v. 31, n. 1, p. $99-109,1996$

KURTAR, E. S. Modelling the effect of temperature on seed germination in some cucurbits. Afr. J. Biotechnol., v. 9, n. 9, p. $1343-1353,2010$.

LE NARD, M.; DE HERTOGH, A. A. Tulipa. In: DE HERTOGH, A.; LE NARD, M. (Eds.). The physiology of flower bulbs. Amsterdam: Elsevier Science Publishers, 1993. p. 617-682.

LU, P. et al. Effects of environmental factors on germination and emergence of crofton weed (Eupatorium adenophorum) Weed Sci., v. 54, n. 3, p. 452-457, 2006.

MACK, J. J. Workplan for lesser celandine (Ranunculus ficaria) control in Rocky River and Mill Stream Run Reservations. Cleveland: Division of Natural Resources, Fairview Park, 2008. (v.1.0. Cleveland Metroparks Technical Report 2008/NR-05)

MARIA, B. et al. Age and size structure in populations of a long-lived dioecious geophyte: Borderea pyrenaica

(Dioscoreaceae). Intern. J. Plant Sci., v. 156, n. 2, p. 236-243, 1995.

MARKHAM, B. An eco-physiological study of Ranunculus ficaria $\mathrm{L}$. in relation to light and temperature. 1970. Thesis (Ph.D.) - University of London, London, 1970.
MOSER, B. C.; HESS, C. E. The physiology of tuberous root development in Dahlia. Proc. Am. Soc. Hortic. Sci., v. 93, n. 6, p. 595-603, 1968.

NORSWORTHY, J. K.; OLIVERIA, M. J. Sicklepod (Senna obtusifolia) germination and emergence as affected by environmental factors and seeding depth. Weed Sci., v. 54, n. 5, p. 903-909, 2006.

OHKAWA, K. growth and flowering of Ranunculus asiaticus. Acta Hortic., (ISHS), v. 177, p. 165-172, 1986. Available from URL: <http://www.actahort.org/books/177/ 177_22.htm>. Accessed: Aug. 312011.

SELL, P. D. Ranunculus ficaria L. sensu lato. Watsonia, v. 20, n. 1, p. 41-45, 1994.

SHAVER, G. R.; BILLINGS, W. D. Carbohydrate accumulation in tundra graminoid plants as a function of season and tissue age. Flora, v. 165, n. 3, p. 247-267, 1976.

SWEARINGEN, J. M. Lesser Celandine (Ranunculus ficaria). Available from URL: <http://www.nps.gov/plants/ alien/fact/rafi1.htm>. Accessed: Mar. 152011.

VIDAL, R. A. et al. Impact of temperature, light and seed depth on emergence and germination of Conyza bonariensis and Conyza Canadensis resistant to glyphosate

Planta Daninha, v. 25, n. 2, p. 309-315, 2007.

TAYLOR, K.; MARKHAM, B. Biological flora of the British Isles. Ranunculus ficaria L. J. Ecol., v. 66, n. 3, p. 1011-103, 1978.

TRAVLOS, I. S. et al. Potential effects of diurnally alternating temperatures and solarization on purple nutsedge (Cyperus rotundus) tuber sprouting. J. Arid Environ., v. 73, n. 1, p. $22-25,2009$ 